\title{
Attributes Ensuring Positive Consumer Evaluation in Brand Extension of Pakistan
}

Malik Shahzad Shabbir, University of Lahore, Pakistan

\begin{abstract}
Brand extension is an important cost-effective marketing method to offer new products. However, ordinary Least Square regression with control variables has been applied for estimation of variable coefficients. In the study, consumer evaluation of brand extension in Pakistan is dependent on quality of the original brand, substitutability of the extension with the original brand in certain usage situation and helpfulness of people, facilities and skills used in developing, refining and making the original brand for constructing its extension. Furthermore, other independent variables including complementarity, difficulty and moderating the role of quality of the original brand with fit attributes has been found irrelevant for determining consumer evaluation of brand extension in Pakistan. The author has found an expected significant outcome on the ideal point effect of substitutability at $15 \%$.
\end{abstract}

\section{KEYWORDS}

Brand Extension, Brand Management, Consumer Evaluation, Consumer Preference, Marketing

\section{INTRODUCTION}

Brand extension is an important marketing method to offer new products. The method has achieved both successes and failures in Pakistan: Jang, a category leader in Urdu newspapers had extended its spin-off, Geo News, in electronic media category. Over a period of time, Geo News also became a category leader. However, Waqt, a news channel of Nawai Waqt, $2^{\text {nd }}$ best Urdu newspaper, has failed to position itself in electronic media category. Similarly, Dawlance, leader in refrigerator category could not position itself in television and microwave categories. Why some failed, but others succeed? Subsequently, a number of similar studies were conducted in various countries.

Purchase intention is the implied promise to one's self to buy the product again whenever one makes next trip to the market (Fandos \& Flavian, 2006; Halim \& Hameed, 2005). It has a substantial importance because the companies want to increase the sale of specific product for the purpose to maximize their profit. Purchase intention depicts the impression of customer retention. There are certain functions of the brand which have a strong influence on the purchase intention of the customer's i.e. brand image, product quality, product knowledge, product involvement, product attributes and brand loyalty.

Firms are considered good and bad not only on the basis of their behaviors in the ethical domain but also from the ways their products perform. Previous research supports the notion that negative information about product attributes influences consumers' attitudes toward brands more than does positive information about product attributes (Herr, Kardes, \& Kim, 1991). Although attribute performance suggests how to classify the product (Herr et al., 1991), such information may be much less diagnostic of a firm's underlying characteristics. Firms may have reasons for offering 
low-quality products that do not suggest bad character a low-quality product is designed to serve a segments' need for a low-priced product. If so, consumer attitudes should differ depending on firm ethics regardless of product attribute inferiority. Shabbir et al. (2016) at some extent, some of the social media applications in the present time have become most efficient and effective tool for small business entrepreneurs and normally all small business use social media platform for the advertising and publicity of their products and services, they make fan pages for the followers and they warmly welcome the suggestions and opinions which help in improving their business.

To maximize the acceptance and recognition of new products in Pakistan, it is appropriate to test the theory by hypothesizing that favorable consumer evaluation of brand extension in Pakistan is dependent on attributes of complementarity, substitutability, transferability and difficulty, and the indirect effect of parent brand quality through moderating role of quality on the complementarity and substitutability. To maximize the acceptance and recognition of new products in Pakistan, it is appropriate to test the theory for Pakistan. We have used survey method (Likert scale 1-7) to determine attributes of consumer evaluation of brand extension in Pakistan.

The concept of brand equity has been discussed and explained by several studies. Brand equity is been explained through two major perspectives financial aspect and marketing aspect. Brands used to be associated with products, but it has been a consideration on corporate brands (Mott ram, 1998). Brand equity refers to the endowed value in the mind of the customer. Brand image and brand awareness are the factors which creates perception in the mind of the customer and these factors eventually add value in brand equity (Pina 2003). The important concept here is consumer memory. Associative model conveys that memory is the set of interlinked nodes and links (Wryer \& Srull, 1989; Keller, 1993). Brand extension is the extended or additional product within the same or different category of the same brand. Brand extensions strategies are assumed to increase the efficiency of the firm's investment in advertisement and creating awareness through advertisement (Aaker, 1990; Simon \& Sullivan, 1991; Tauber, 1988).

Brand extension usually considered as profitable both ways, horizontally and vertically, but there is a possibility of bearing extra expense of bringing on the new product in the market for example product introduction and advertisement would need certain amount of expanses on it (Collin-Dodd \& Louver, 1999; Tamber, 1988). The brand extension strategies in consumer goods are not more profitable than other markets for example automobile industry. Automobile industry observed successful brand extensions as new model of any brand comes, it automatically get noticed by its customers. Successful brand spent less on advertising rather new product development. Investment on developing established brands, companies cut the cost of launching brand extension (Xie, 2008).

This study addresses two objectives such as, at what extent original brand quality, substitutability, complementarity, transfer and difficulty are positively related with consumer evaluation of brand extension. Whereas, original brand quality moderating with the three fit attributes, namely, substitutability, complementarity and transfer are positively related with consumer evaluation of brand extension. The objective of this study is to examine the impact of positive consumer evaluation in brand extension of Pakistan. For this purpose, this study has taken several brands as a case studies for their second brands or extension of existing brands in various ways.

Brand Extension category is a new concept in Pakistani brand industry as well as in corporate sector. This is an emerging combination of brand to brand extension that provides a brand real chance to gain competitive advantages rather than other brands. Through its spiritual application in different brand sectors of Pakistani brand sector we can enjoy a real increasing trend regarding a brand extension. This research investigation indicates some useful implications for Pakistani brands as we found a very strange relation. This research tried to provide a better understanding of consumers' evaluation of a fashion brand extending into fashion categories, by comprehensively reviewing previous research relating to this subject, and developing a research rationale. 


\section{LITERATURE REVIEW}

Based on two sets of social psychology theory including associative memory network model and categorization theory, brand extension theory has been evolving since 1990. In terms of brand extension theory, higher quality perceptions about the original brand are associated with favorable attitudes for the extension. Further, congruence between the original brand associations and the new category concepts is reflected through the three fit attributes. This particular attribute is perhaps more helpfully conceived as the opposite of triviality, in the sense that subjects might evaluate trivial extensions poorly, like Engro Food is marketing ball point pen.

Halim and Hameed (2005) explain purchase intention as the number of patrons that has a proposal to buy the products in future and make repetition purchases and contact again to the specific product. In and Kang (2011) explains purchase intention relating four behaviors of consumers including the undoubted plan to buy the product, thinking unequivocally to purchase the product, when someone contemplate to buy the product in the future, and to buy the specific product utterly. Fandos and Flavian (2006) explain the phenomenon of purchase intention as the projected behavior of consumers on short basis about the repetition purchase of specific product i.e. when someone decided to buy the product whenever he/she will come again to the market.

Arslan and Altuna (2010) defined brand image as the positive and negative feeling about the brand when it comes to the mind of the consumers abruptly or when they recall their memories. They have the view that there are three aspects of brand image which make the whole image of the brand which are; favorability, strength, and distinctiveness. Meenaghan (1995) explains brand image in terms of the attitudes of the consumers about the particular brand which helps to point it and thinking of the buyers in the significant way to make the product different from others. Bian and Moutinho (2011) described the phenomenon by using marketing sense to explain it as the set of statements given to the target market to capture the purchase intentions of the targeted consumers. Lee, Lee and Wu (2011) explain the brand image as the overall mind reflection and beliefs about the particular brand by keeping in mind its unique qualities which make it different from the others. Sebastianelli and Tamimi (2002) explained product quality as something which resembles with the innate excellence, which mean, it comes from the production level and it should be recognizable. They emphasized that quality should consist of measurable features instead of preferences.

Shabbir (2016) analyzed the effect of media on buying behavior of children in Pakistan. However, comparatively we have analyzed how the parents and peers play their roles in making buying decision of their children. We have used primary data to find out consumer socialization and factors that affect children influencing and final decision making in doing any purchase.In the contemporary business world, the competition among firms is different from the past as this is understated which is little but very crucial. The firms are attempting for competitiveness that help them to hold more stable place in the market. The ideal route for firms to attain it is with the innovation (Shabbir MS 2015).

In last few decades researchers have made noteworthy contributions and aid for explaining how consumers evaluate brand extension. (Riley et al., 2004). As current reviews of the literature indicated (Czellar, 2003; Grime et al., 2002), there has been a plethora of research on consumer attitudes to and evaluation of brand extensions and on their impact on the 'equity' of the parent brand. Particularly much of this research has been of generalization and replication kind, particularly of Aaker and Keller's (1990) paper (Sunde \& Brodie, 1993; Bottomley \& Doyle, 1996). Aaker and Keller (1990) in the paper "Consumer Evaluations of Brand Extensions" conducted an exploratory research in the consumer product setting to gain knowledge on how consumers form attitudes toward brand extensions strategy by testing 4 hypotheses based on 6 deep-rooted successful brands, 20 hypothetical brand extensions (e.g. Heineken beer to Heineken wine and Heineken popcorn) and having sample size of 107 respondents.

New brand involves creation of names especially when entering a new product category. For example, Coca Cola entered the mineral water bottle segment with a new band name Kinely and 
Honda created the Acura brand to differentiate its luxury car from its established Honda line (Kotler $\&$ Armstrong, 2005). Line extension was extending the existing brand names to new forms, sizes and flavors of an existing product category under the same brand name. For example, Colgate has extended its brand name in the toothpaste category from Colgate to Colgate gel, Colgate herbal, Colgate sensitive, Colgate calciguard and Colgate total. It involves introduction of additional brands in the same product category. For example, PNG in Pakistan markets many different brands in each of its product categories. (Kotler \& Armstrong, 2005).

A brand Extension involves extending a successful brand name to launch another new product, either in the same or a different product category. As the cost of establishing a new brand was high, brand extension can be a useful tool for the cost-effective launch of a new product. Familiarity with an existing brand also helps both customers and marketers Hummera et al. (2019). Customers extend the qualities associated with the existing brand to the new brand. Market acceptance of the new product becomes faster. Maggi has been extended from noodles to product lines in related categories like Maggi ketchup, Maggi soup, etc. (Kotler \& Armstrong, 2005).

Whereas, Shabbir and Zaman (2016) explore and pinpoint some of marketing strategies issues which can be helpful for new investors and old stakeholders in the sector of Islamic banking in Pakistan, In order to penetrate successfully in the market. Furthermore, this stud investigates that what can be suitable and effective marketing strategies for Islamic Banking in Pakistan? Their target groups are those Islamic banks and standalone Islamic bank branches that are currently working in Pakistani market and those who are interested in exploring the Pakistani market.

\section{METHODOLOGY}

As in associative memory model, it is discussed that customer remember experiences and on the basis of their experiences their loyalty increases. Manager's efforts in this regard are very essential as without manager's market sense and forecasting company cannot predict success and failure of child product. When considering the relationship of parent and child brand it is revealed that when applying brand extension strategies two possibilities are obvious. Either child brand carrying the parent name with its own name and other one is child brand is launched independent apart from parent name with its own name. Multiple effects have observed for this phenomenon. Firstly, those products which are carrying parent brand with their own name are taking risk of their reputation and image in customer's mind. If child product does not build its reputation as its parent company has already established, then it will be threat for parent company because its name is on stake. And people can always show their dissonance by switching to another brand of different company. On the other hand, when new brand is launched independently (without carrying its parent brand) then it may be a possibility that customer get unaware of the parent brand name and brand equity will not transferred to parent brand account. In Pakistani market perspective, market is stagnant and bounded in boundaries.

Based on our hypothesis, the following regression model has been developed:

$Y=\alpha+\beta_{1} x_{1}+\beta_{2} x_{2}+\beta_{3} x_{3}+\beta_{4} x_{4}+\beta_{5} x_{5}+\beta_{6} x_{1} x_{2}+\beta_{7} x_{1} x_{3}+\beta_{8} x_{1} x_{4}+\varepsilon$

$\mathrm{Y}=$ brand extension preference (average of try and quality of brand extension)

$\alpha=$ constant intercept

$\mathrm{X} 1=$ original brand preference

$\mathrm{X} 2=$ level of substitutability

$\mathrm{X} 3$ = level of complementarity

$\mathrm{X} 4=$ level of transfer

$\mathrm{X} 5=$ level of difficulty

$\beta_{6}$ to $\beta_{8}=$ interaction of fit attributes with original brand quality in case of OLS technique and residuals in case of $\mathrm{RC}$ technique

$\varepsilon=$ homoscedastic $\&$ independent error term 
To test the hypothesis of this study, the data on relevant attributes is collected through sample survey method. The ordinary least square regression method with RC technique has been applied on the survey data for estimation of the coefficients and sign of the relationship. However, Pakistan is consisting of five provinces and other areas with 175 million populations spreading over 1,046 km area. Karachi is a business hub of the country having population representing all the provinces. As such, the probability that Karachi is representative of Pakistan's population is much higher than other cities. In terms of judgment sampling, 147 university students and working professionals participated in the study (As such, total observations are 438). It was ensured that all are actual users of the selected brands. The six original brands and the extensions were selected as per criteria prescribed by Aaker and Keller (1990) discussed in this paper elsewhere. Further, it was also ensured that the extension should be logical and heterogeneous on the three fit measures. The following is the list of original brands and their extensions (Table 4).

\section{RESULTS}

Brand extension theory was first tested by Aaker and Keller (1990), who theorized original brand quality (OBQ), together with three 'fit' attributes of substitutability (Subst), complementarity (Compl), transferability (Trans) and non-fit attribute, difficulty (Diffi) has a direct effect on the preference for the new brand extension (BEPrefrnc). They also hypothesized that there is an interactive effect between quality and the three fit attributes.

With this theory, they developed the following model to test the theory:

\section{$\mathrm{BEPrefrnc}=\mathrm{OBQ}+$ Subst + Compl + Trans + Diffi + OBQ $*$ Subst + OBQ $*$ Compl + OBQ*Trans}

In order to estimate the above model, they employed six actual brands (prior to selection of the actual brand, it was ensured that these brands meet the three criteria of high quality, strong brand image and no prior significant extension) and 20 hypothetical brand extensions for a sample of 107 undergraduate business students of Berkley University in USA. These attitudes were measured on 7 -point Likert scales where 1 was semantically anchored as a low level and 7 as a high level. They run OLS regression on the data and found the following results (Table 1):

Based on the theory and the empirical findings of Aaker and Keller (1990), a number of authors run similar model for their respective countries. Subsequently, it was argued that due to existence of multi-collinearity, it is appropriate to run residual centering (RC) technique for estimation of the coefficients (Echambadi et al., 2004). The results of significance of these studies including Aaker and Keller are given in the following Table 2.

Mather (2011) has commented that residual centering was used in many of the replication studies in order to eliminate the multicollinearity. In view of his observations, Mather (2011) collected the data sets from previous empirical studies (some of them are noted in Table 2) and run General Linear Mixed Model (GLMM). Based on which, he concluded that complementarity, substitutability and transferability and the indirect effect of original brand quality via quality's moderating role on the

Table 1. Regression results of the model (1) of Aaker \& Keller (1990)

\begin{tabular}{|c|c|c|c|c|c|c|c|c|}
\hline & OBQ & Trans & Compl & Subst & OBQ ${ }^{*}$ Trans & OBQ $*$ Compl & OBQ*Subst & Diffi \\
\hline $\begin{array}{l}\text { Regression } \\
\text { coefficient }\end{array}$ & -0.01 & 0.12 & -0.02 & -0.06 & 0.02 & 0.03 & 0.02 & 0.12 \\
\hline $\mathrm{t}$-value & -0.1 & 2.0 & -0.4 & -1.0 & 1.4 & 3.2 & 2.1 & 6.2 \\
\hline
\end{tabular}


Table 2. Regression results of other important studies

\begin{tabular}{|c|c|c|c|c|c|c|c|c|c|}
\hline \multirow{2}{*}{ Author } & \multirow{2}{*}{ Country } & \multicolumn{4}{|c|}{ Fit attributes } & \multirow{2}{*}{ D } & \multicolumn{3}{|c|}{ Interaction terms } \\
\hline & & $\mathbf{Q}$ & $\mathbf{C}$ & $\mathbf{S}$ & $\mathbf{T}$ & & $Q \times C$ & $Q \times S$ & Q X T \\
\hline Aaker \& Keller & USA & $\mathrm{N}$ & $\mathrm{N}$ & $\mathrm{N}$ & $\mathrm{Y}$ & $\mathrm{Y}$ & $\mathrm{Y}$ & $\mathrm{Y}$ & $\mathrm{N}$ \\
\hline Sunde \& Brodie & New Zealand & $\mathrm{Y}$ & $\mathrm{N}$ & $\mathrm{Y}$ & $\mathrm{N}$ & $\mathrm{N}$ & $\mathrm{N}$ & $\mathrm{Y}$ & $\mathrm{N}$ \\
\hline Nijssen and Hartman & Netherlands & $\mathrm{Y}$ & $\mathrm{N}$ & $\mathrm{Y}$ & $\mathrm{Y}$ & $\mathrm{N}$ & $\mathrm{N}$ & $\mathrm{Y}$ & Y \\
\hline Alexandre-Bourhis & France & $\mathrm{N}$ & $\mathrm{Y}$ & $\mathrm{Y}$ & $\mathrm{Y}$ & $\mathrm{N}$ & $\mathrm{N}$ & $\mathrm{N}$ & $\mathrm{N}$ \\
\hline Bottomley and Doyle & U.K. & $\mathrm{N}$ & $\mathrm{N}$ & $\mathrm{Y}$ & $\mathrm{N}$ & $\mathrm{N}$ & $\mathrm{Y}$ & $\mathrm{N}$ & $\mathrm{Y}$ \\
\hline $\begin{array}{l}\text { Barrat, Lye \& } \\
\text { Venkateswarlu }\end{array}$ & New Zealand & $\mathrm{Y}$ & $\mathrm{Y}$ & $\mathrm{Y}$ & $\mathrm{Y}$ & $\mathrm{N}$ & $\mathrm{N}$ & $\mathrm{N}$ & $\mathrm{Y}$ \\
\hline Holden and Barwise & U.K. & Y & $\mathrm{Y}$ & $\mathrm{Y}$ & Y & $\mathrm{Y}$ & $\mathrm{N}$ & $\mathrm{N}$ & $\mathrm{Y}$ \\
\hline Fu and Saunders & China & $\mathrm{N}$ & $\mathrm{N}$ & $\mathrm{N}$ & $\mathrm{Y}$ & $\mathrm{Y}$ & $\mathrm{Y}$ & $\mathrm{N}$ & $\mathrm{N}$ \\
\hline Patro and Jaiswal & India & $\mathrm{Y}$ & $\mathrm{Y}$ & $\mathrm{Y}$ & $\mathrm{Y}$ & $\mathrm{N}$ & $\mathrm{N}$ & $\mathrm{N}$ & $\mathrm{Y}$ \\
\hline
\end{tabular}

Note: Y denotes 'significant' and N 'not significant' at 95\% C.L. Source: (Mather, 2011)

intrinsic effect of complementarity and substitutability affect consumer evaluation of brand extension positively and found the following results (Table 3):

With respect to brand extension research carried out in Pakistan, we have found three studies. Durrani and Hussain (2009) evaluated successful brand extension based on survey method of telephone interviews with brand managers of Z-Jans (healthcare), Chen One (retail), Haleeb (dairy) and face to face interviews with Lakson (media/fast food/consumer goods) and Serves Groups (shoes/ pharma/tires \& tubes). He concluded that brand management in Pakistan is at rudimentary stage of development and that brand extension with low price and value for customer is likely to perform well for Pakistani market. Ahmad, Abrar, Rehman and Kashif et al (2009) studied the relationship between brand loyalty and brand extension and found effective relation, loyalty behavior, self-image and similarity as significant variables to explain positive brand extension evaluation. Jalees and Ali (2008) examined and empirically tested how consumers in Pakistan evaluate close brand extension in reference to variables including, similarly, reputation, multiple brand extension, parent brand characteristics and brand concept characteristics with a sample of 700 persons in Karachi following Ordinary Least Square method, they found similarity and reputation as significant variable. However, none of them has followed Aaker and Keller's model and its subsequent development.

Consumer attributes were gathered on seven-point Likert scales (1 being low, 7 being high). The consumer's overall attitude towards the extension was taken as dependent variable. As per practice in the literature, the dependent variable was an average of two dimensions including (a) overall perceived quality of the extension brand and the purchasing probability of buying the extension product. The independent variables measured as (a) quality and (b) difficult. The fit attributes including (c) substitutability, (d) complementarity and (e) transfer were also measured on the seven-point Likert scales (The questionnaire is given on Annexure-I). Every printed questionnaire contained questions to obtain responses on one original brand and three extensions. In order to facilitate respondents,

Table 3. GLMM Results of Mather (2011)

\begin{tabular}{|c|c|c|c|c|c|c|c|c|c|c|c|}
\hline & \multicolumn{4}{|c|}{ Fit attributes } & \multirow{2}{*}{ D } & \multicolumn{3}{|c|}{ Interaction terms } & \multicolumn{3}{|c|}{ Ideal point } \\
\hline & $\mathbf{Q}$ & $\mathbf{C}$ & $\mathbf{S}$ & $\mathbf{T}$ & & $\mathbf{Q} \times \mathbf{C}$ & $Q \times S$ & Q $\times \mathbf{T}$ & $\mathrm{C}^{\wedge} 2$ & $S^{\wedge} 2$ & $\mathbf{T}^{\wedge} 2$ \\
\hline Mather (2011) & $\mathrm{N}$ & Y & Y & $\mathrm{Y}$ & $\mathrm{N}$ & Y & $\mathrm{Y}$ & $\mathrm{Y}$ & $\mathrm{Y}$ & $\mathrm{N}$ & $\mathrm{Y}$ \\
\hline
\end{tabular}


Table 4. Original brands and their hypothetical extensions

\begin{tabular}{|c|c|c|c|c|}
\hline$\#$ & Original Brands & \multicolumn{3}{|c|}{ Extensions } \\
\hline 1 & Tapal Danedar Chai & Coffee & Milk & Mouthwash \\
\hline 2 & K\&N Chicken & Red meat & Masala & Floor tiles \\
\hline 3 & Qurshi's Jam Sheeren & Fruit juice & Mithai (sweet) & Bicycle \\
\hline 4 & Mobilink Mobile Network & Landline Network & Mobile handset & Ball point/ink pen \\
\hline 5 & Olper's Milk & Milk powder & Tea bag & Chewing gum \\
\hline 6 & Student Biryani & Burger & Soft drink & Chewing gum \\
\hline
\end{tabular}

brief explanation, examples and instructions were given wherever appropriate. We followed indirect question administration. A pretest of the questionnaire was conducted with 51 respondents. These respondents were not included in the final survey.

\section{- The Data Characteristics}

The statistic of Skewness and kurtosis of the dependent variable showed normal distribution. Not only this, distribution of all the independent variables is also following normality assumption (Table 5) —although kurtosis statistic for independent variables, have reached as high as 1.24.

\section{- Correlation Matrix}

However, Linearity of independent variables with dependent variable show that all the independent variables are satisfying the assumption of linearity with respect to the dependent variable by showing significant correlation at the 0.01 level (Table 6). The correlation matrix shows high correlation between the three fit attributes and their interaction with quality terms. It is noted that correlation between transferability and difficulty shows a higher side.

\section{- OLS Regression Estimates}

Table 5. Data characteristics

\begin{tabular}{|c|c|c|c|c|c|c|c|}
\hline & \multirow[b]{2}{*}{ Mean } & \multirow{2}{*}{$\begin{array}{c}\text { Std. } \\
\text { Deviation }\end{array}$} & \multicolumn{2}{|c|}{ Skewness } & \multicolumn{2}{|c|}{ Kurtosis } & \multirow[b]{2}{*}{ Mode } \\
\hline & & & Statistic & $\begin{array}{l}\text { Std. } \\
\text { Error }\end{array}$ & Statistic & $\begin{array}{l}\text { Std. } \\
\text { Error }\end{array}$ & \\
\hline \multicolumn{8}{|c|}{ Dependent variable: } \\
\hline Brand Extension Preference & 3.76 & 1.43 & -0.23 & 0.12 & -0.67 & 0.23 & 4.00 \\
\hline \multicolumn{8}{|c|}{ Independent variables: } \\
\hline Original Brand Quality & 4.94 & 1.10 & -0.42 & 0.12 & -0.01 & 0.23 & 5.00 \\
\hline Substitutability & 3.57 & 1.86 & 0.02 & 0.12 & -1.21 & 0.23 & 1.00 \\
\hline Complementarity & 3.47 & 1.87 & 0.06 & 0.12 & -1.24 & 0.23 & 1.00 \\
\hline Transferability & 3.88 & 1.88 & -0.27 & 0.12 & -1.05 & 0.23 & 5.00 \\
\hline Difficulty & 3.79 & 1.72 & -0.22 & 0.12 & -0.99 & 0.23 & 5.00 \\
\hline
\end{tabular}


Table 6. Correlation matrix

\begin{tabular}{|l|c|c|c|c|c|c|c|c|c|}
\hline & BEPrefrnc & OBQ & Subst & Compl & Trans & Diffi & OBQxSubst & OBQxCompl & OBQxTrans \\
\hline BEPrefrnc & 1 & $0.17^{* *}$ & $0.73^{* *}$ & $0.53^{* *}$ & $0.67^{* *}$ & $0.62^{* *}$ & $0.71^{* *}$ & $0.52^{* *}$ & $0.66^{* *}$ \\
\hline OBQ & $0.17^{* *}$ & 1 & $0.08^{*}$ & $0.12^{* *}$ & 0.04 & $0.11^{* *}$ & $0.42^{* *}$ & $0.44^{* *}$ & $0.44^{* *}$ \\
\hline Subst & $0.73^{* *}$ & $0.08^{*}$ & 1 & $0.55^{* *}$ & $0.57^{* *}$ & $0.56^{* *}$ & $0.92^{* *}$ & $0.51^{* *}$ & $0.53^{* *}$ \\
\hline Compl & $0.53^{* *}$ & $0.12^{* *}$ & $0.55^{* *}$ & 1 & $0.42^{* *}$ & $0.45^{* *}$ & $0.53^{* *}$ & $0.92^{* *}$ & $0.42^{* *}$ \\
\hline Trans & $0.67^{* *}$ & 0.04 & $0.57^{* *}$ & $0.42^{* *}$ & 1 & $0.79^{* *}$ & $0.52^{* *}$ & $0.39^{* *}$ & $0.89^{* *}$ \\
\hline Diffi & $0.62^{* *}$ & $0.11^{* *}$ & $0.56^{* *}$ & $0.45^{* *}$ & $0.79^{* *}$ & 1 & $0.54^{* *}$ & $0.44^{* *}$ & $0.74^{* *}$ \\
\hline OBQxSubst & $0.71^{* *}$ & $0.42^{* *}$ & $0.92^{* *}$ & $0.53^{* *}$ & $0.52^{* *}$ & $0.54^{* *}$ & 1 & $0.62 * *$ & $0.65 * *$ \\
\hline OBQxCompl & $0.52^{* *}$ & $0.44^{* *}$ & $0.51^{* *}$ & $0.92^{* *}$ & $0.39^{* *}$ & $0.44^{* *}$ & $0.62^{* *}$ & 1 & $0.54 * *$ \\
\hline OBQxTrans & $0.66^{* *}$ & $0.44^{* *}$ & $0.53^{* *}$ & $0.42^{* *}$ & $0.89^{* *}$ & $0.74^{* *}$ & $0.65^{* *}$ & $0.54^{* *}$ & 1 \\
\hline
\end{tabular}

${ }^{* *}$ Correlation is significant at the 0.01 level (1-tailed)

* Correlation is significant at the 0.05 level (1-tailed)

Running the OLS regression for equation produces the following estimates (Table 7):

As evident from the above regression estimates, none of the independent variables has been found significant due to high collinearity as indicated in very low levels for tolerances. This may be due to highly collinear independent variables as discussed elsewhere in the paper. When there is high multicollinearity between the independent variables, relationship between the independent variables and the dependent variables is likely to be ambiguous. Avoiding multicollinearity is particularly important for us in this paper because various authors have questioned the OLS estimation and residual centering technique as inadequate measures to eliminate multicollinearity (Bottomley \& Doyle, 1996, Lance, 1988; Mather, 2011).

In order to resolve the issue of multicollinearity without compromising on objective of finding best, linear, unbiased estimates, we divide the collinear independent variables into two following categories and run regression separately:

Category-A

Difficulty

OBQxSubst

OBQxComple

OBQxTrnsfr

SqrSubsti

SqrComp

SqrTrnsfr

Category-B

Substitutability

Complementarity

Original Brand Quality

Transferability

\section{- OLS Regression Estimation with Category-A}

Regression estimates with independent variables under Category-A are given in Table 8: 
Table 7. OLS Regression for the Model as per Equation

\begin{tabular}{|c|c|c|c|c|c|c|c|c|}
\hline & \multirow{2}{*}{ Model } & \multirow{2}{*}{\multicolumn{2}{|c|}{$\begin{array}{c}\begin{array}{c}\text { Standardized } \\
\text { Coefficients }\end{array} \\
\text { Beta }\end{array}$}} & \multirow{2}{*}{ T-test } & \multirow{2}{*}{\multicolumn{2}{|c|}{ Sig. }} & \multicolumn{2}{|c|}{ Collinearity Statistics } \\
\hline & & & & & & & Tolerance & VIF \\
\hline \multirow{12}{*}{1} & (Constant) & & & 1.046 & \multicolumn{2}{|c|}{0.297} & & \\
\hline & Substitutability & & 0.332 & 1.162 & \multicolumn{2}{|c|}{0.246} & 0.018 & 56.720 \\
\hline & Complementarity & & 0.129 & 0.449 & \multicolumn{2}{|c|}{0.654} & 0.017 & 57.912 \\
\hline & $\begin{array}{c}\text { Original Brand } \\
\text { Quality }\end{array}$ & & 0.068 & 0.667 & \multicolumn{2}{|c|}{0.506} & 0.139 & 7.170 \\
\hline & Transferability & & 0.260 & 0.964 & \multicolumn{2}{|c|}{0.336} & 0.020 & 50.789 \\
\hline & Difficulty & & 0.055 & 0.835 & \multicolumn{2}{|c|}{0.405} & 0.329 & 3.037 \\
\hline & OBQxSubst & & 0.245 & 0.930 & \multicolumn{2}{|c|}{0.353} & 0.021 & 48.368 \\
\hline & OBQxComple & & 0.155 & -0.649 & \multicolumn{2}{|c|}{0.517} & 0.025 & 39.903 \\
\hline & OBQxTrnsfr & & 0.093 & 0.394 & \multicolumn{2}{|c|}{0.694} & 0.026 & 39.061 \\
\hline & SqrSubsti & & 0.118 & -0.558 & \multicolumn{2}{|c|}{0.578} & 0.032 & 31.261 \\
\hline & SqrComp & & 0.066 & 0.318 & \multicolumn{2}{|c|}{0.751} & 0.034 & 29.796 \\
\hline & SqrTrnsfr & & 0.002 & 0.012 & \multicolumn{2}{|c|}{0.990} & 0.036 & 27.536 \\
\hline R square & $\begin{array}{l}\text { Adjusted R } \\
\text { square }\end{array}$ & $63 \%$ & $\begin{array}{l}\text { D-W } \\
\text { statistic }\end{array}$ & 1.537 & $\begin{array}{c}\text { Regression } \\
\text { sum of } \\
\text { squares }\end{array}$ & 373.040 & $\begin{array}{l}\text { Residual sum } \\
\text { of squares }\end{array}$ & 203.935 \\
\hline
\end{tabular}

We found interaction of original brand quality and substitutability significant at 0.05 levels. But we cannot interpret the relationship of this variable with dependent variable as 'true' because tolerance level of this variable is below $10 \%$.

\section{- OLS Regression Estimation with Category-B}

Regression estimates with independent variables under Category-B are given in Table 9:

The category-B results show substitutability, original brand quality and transferability as contributing towards positive consumer evaluation of brand extension to a very significant extent. We did not find complementarity attributes as significant. Further, the issue of multicollinearity in the all the independent variables has also been resolved completely. The value of D-W statistics of 1.55 is within the prescribed range for rejection of presence of serial correlation among the residuals. Further, this border line value of the D-W statistic is of very little concern because we are dealing with cross-sectional data. The same level of $\mathrm{R}^{2}$ and adjusted $\mathrm{R}^{2}$ indicate towards no discrepancy in including/excluding of the variables in the model. Regarding model fit, regression sum of squares are 371 , much higher than residual sum of square of 206. As such, the true model for consumer evaluation of brand extension in Pakistan is as follows;

Positive extension evaluation $=\alpha+$ Original Brand Quality + Substitutability + Transfer $+\varepsilon$

With category-B independent variables, we included independent variables under category-A one-by-one. After obtaining the coefficient of the included variable, we replaced the old variable with the new till all the following coefficients were estimated. Non-significance of these variables indicates that category-A variable are not relevant in consumer evaluation modeling of brand extension in Pakistan (Table 10). 
Table 8. OLS Regression with independent variables given in the Category-A

\begin{tabular}{|c|c|c|c|c|c|}
\hline \multirow{2}{*}{ Model } & \multirow{2}{*}{$\begin{array}{c}\begin{array}{c}\text { Standardized } \\
\text { Coefficients }\end{array} \\
\text { Beta }\end{array}$} & \multirow{2}{*}{ T-test } & \multirow{2}{*}{ Sig. } & \multicolumn{2}{|c|}{ Collinearity Statistics } \\
\hline & & & & Tolerance & VIF \\
\hline (Constant) & & 11.317 & 0.000 & & \\
\hline Difficulty & 0.100 & 1.564 & 0.119 & 0.358 & 2.793 \\
\hline OBQxSubst & 0.388 & 1.938 & 0.054 & 0.036 & 27.600 \\
\hline OBQxComple & -0.113 & -0.647 & 0.518 & 0.047 & 21.171 \\
\hline OBQxTrnsfr & 0.118 & 0.738 & 0.461 & 0.056 & 17.713 \\
\hline SqrSubsti & 0.078 & 0.460 & 0.646 & 0.050 & 19.859 \\
\hline SqrComp & 0.166 & 1.111 & 0.267 & 0.065 & 15.394 \\
\hline SqrTrnsfr & 0.205 & 1.506 & 0.133 & 0.078 & 12.772 \\
\hline
\end{tabular}

Table 9. OLS Regression with independent variables given in the Category-B

\begin{tabular}{|c|c|c|c|c|c|c|c|c|c|}
\hline \multirow{2}{*}{\multicolumn{2}{|c|}{ Model }} & \multirow{2}{*}{\multicolumn{3}{|c|}{$\begin{array}{c}\text { Standardized Coefficients } \\
\text { Beta }\end{array}$}} & \multirow{3}{*}{$\begin{array}{l}\text { T-test } \\
1.175\end{array}$} & \multirow{2}{*}{\multicolumn{2}{|c|}{ Sig. }} & \multicolumn{2}{|c|}{ Collinearity Statistics } \\
\hline & & & & & & & & Tolerance & VIF \\
\hline \multicolumn{2}{|c|}{ (Constant) } & & & & & \multicolumn{2}{|c|}{0.241} & & \\
\hline \multicolumn{2}{|c|}{ Substitutability } & \multicolumn{3}{|c|}{0.440} & 8.500 & \multicolumn{2}{|c|}{0.000} & 0.527 & 1.897 \\
\hline \multicolumn{2}{|c|}{ Original Brand Quality } & \multicolumn{3}{|c|}{0.139} & 3.672 & \multicolumn{2}{|c|}{0.000} & 0.979 & 1.021 \\
\hline \multicolumn{2}{|c|}{ Transferability } & \multicolumn{3}{|c|}{0.382} & 7.829 & \multicolumn{2}{|c|}{0.000} & 0.593 & 1.686 \\
\hline \multicolumn{2}{|c|}{ Complementarity } & \multicolumn{3}{|c|}{0.064} & 1.449 & \multicolumn{2}{|c|}{0.149} & 0.714 & 1.400 \\
\hline R square & 0.643 & $\begin{array}{l}\text { Adjusted R } \\
\text { square }\end{array}$ & 0.638 & $\begin{array}{c}\text { D-W } \\
\text { statistic }\end{array}$ & 1.546 & $\begin{array}{c}\text { Regression } \\
\text { sum of } \\
\text { squares }\end{array}$ & 371.242 & $\begin{array}{l}\text { Residual sum of } \\
\text { squares }\end{array}$ & 205.734 \\
\hline
\end{tabular}

Table 10. Combined results of both categories

\begin{tabular}{|c|c|c|c|c|c|c|c|}
\hline Test & Difficulty & OBQxSubst & OBQxComp & OBQxTrsfr & Subs`2 $^{\text {CBomp }}$ & Trnsfr^2 $^{\wedge}$ \\
\hline T-statistic & 0.735 & 0.170 & 0.015 & 0.136 & -0.048 & 0.027 & 0.054 \\
\hline Significance & 0.463 & 0.850 & 0.988 & 0.690 & -0.269 & 0.150 & 0.957 \\
\hline Tolerance & 0.332 & 0.035 & 0.037 & 0.036 & 0.044 & 0.043 & 0.046 \\
\hline
\end{tabular}

\section{CONCLUSION}

As per our study, consumer evaluation of brand extension in Pakistan is dependent on quality of the original brand, in certain usage situation and helpfulness of people, for making its extension. Further, other independent variables including complementarity, difficulty and moderating role of quality with fit attributes have been found as irrelevant for determining consumer evaluation of brand extension in Pakistan. We have however found an expected sign on ideal point effect of substitutability but significant at $15 \%$ C.L.

Based on our results and the results of authors as reported in Table 2, we are of the view that generalization of consumer evaluation of brand extension at the world level is inappropriate. The results will vary from country to country. Now it is clear that why Dawlance, leader in refrigerator category could not position itself in television and microwave categories due to incongruent nature of the extensions with the original brand and evident helplessness of Dawlance people, facilities 
and skills in making TV/microwave. Similar to this Jang, a category leader in Urdu newspapers had successfully extended its spin-off Geo News, in electronic media category due to quality of the original brand and substitutability of Geo News with that of Jang, newspaper. But failure of Waqt, an electronic news channel was due to low quality of its people, facilities and skills, which was very useful in case of Geo News. Success of this transfer is evident from a fact that a number of reporters/ journalists of Jang News have earned name as TV anchors.

Brand extension strategies can be a cause of success or failures for an extended product as well as these strategies are powerful enough to distort the image of a company. Through literature and interviews the phenomenon that is observed is consumer memory. Consumer always remembers their first interaction with the child brand and compares this with when they first time use parent brand. Consumer recall their good and bad experience with a product either it could be a parent brand or child brand. Once good or bad image is developed it is very difficult to change people's perception. Similar is the case when launching product in different category, it may either add value or may distort the image of the company. When customer loyalty with one brand is developed and relationship of trust is there then every time whenever an extended product is launched they check the consistency among the features of parent brand and child brand and on the basis of previous knowledge and experience with the parent brand customers evaluate child brand. Strong advertisement is a tool when develop loyalty in customer, for example sequels of parent and child products are effective in this regard and many more other things depends on product to product can put positive impact.

\subsection{Recommendation and Implication}

Brand Managers may utilize consumers' perception of quality of their original brand for marketing extension brands. They should realize that 'perception of quality' is the major effect in Pakistan. Brand managers should never compromise on quality. Further, investment to build brand equity is the right approach. Perception of quality of the original brand is the most important factor for successful brand extension. Brand managers can go for similar brand extension where transfer of company resources and skill set is significant.

Brand management research can build on results of this study. The negative sign on polynomial term for substitutability indicated towards existence of ideal point effect, although its significance is at $15 \%$ C.L. Further, all the category-A variables were found insignificant at 5\% C.L. Therefore, it is possible that these variables are irrelevant in Pakistan's context. If so, generalization of brand extension at a world level is not possible. We are of the view that brand extension research should concentrate on finding country specific model instead of generalization at the world level. 


\section{REFERENCES}

Aaker, D. A. (1990). Brand Extensions: The Good, the Bad, and the Ugly. Sloan Management Review, 31(4), 47.

Aaker, D. A., \& Keller, K. L. (1990). Consumer evaluations of brand extensions. Journal of Marketing, 54(1), 27-41. doi:10.1177/002224299005400102

Ahmad, A., Rehman, K. U., Hunjra, A. I., \& Naqvi, S. Q. H. (2009). Impact of Brand Loyalty on Brand Extension. ICME.

Alexandre-Bourhis, N. (1994). L'evaluation Des Extensions De Marque Par Les Consommateurs: Une Etude Empirique. Basse-Normandie, France: Université de Caen.

Alexandris, K., Douka, S., Papadopoulos, P., \& Kaltsatou, A. (2008). Testing the role of service quality on the development of brand associations and brand loyalty. Managing Service Quality, 18(3), 239-254. doi: $10.1108 / 09604520810871865$

Alonso-Almeida, M. D. M., \& Bremser, K. (2013). Strategic responses of the Spanish hospitality sector to the financial crisis. International Journal of Hospitality Management, 32, 141-148. doi:10.1016/j.jjhm.2012.05.004

Bailey, R., \& Ball, S. (2006). An exploration of the meanings of hotel brand equity. Service Industries Journal, 26(1), 15-38. doi:10.1080/02642060500358761

Barret, J., Lye, A., \& Venkateswarlu, P. (1999). Consumer perceptions of brand extensions: Generalising Aaker \& Keller's model. Journal of Empirical Generalisations in Marketing Science, 4(1).

Bergandaa, M. (Ed.). Holden, S.J.S., \& Barwise, P. (1995b). An Empirical Investigation of What It Means to Generalise. In Proceedings of the 24th. EMAC Conference (Vol. 1). ESSEC.

Bian, X., \& Moutinho, L. (2011). The role of brand image, product involvement, and knowledge in explaining consumer purchase behaviour of counterfeits: Direct and indirect effects. European Journal of Marketing, 45(1/2), 191-216. doi:10.1108/03090561111095658

Bottomley, P. A., \& Doyle, J. R. (1996). The Formation of Attitudes Towards Brand Extensions: Testing and Generalizing Aaker and Keller's Model. International Journal of Research in Marketing, 13(4), 365.

Chang, H. H., \& Liu, Y. M. (2009). The impact of brand equity on brand preference and purchase intentions in the service industries. Service Industries Journal, 29(12), 1687-1706. doi:10.1080/02642060902793557

Clark, M. S., \& Fiske, S. T. (Eds.). Mandler, George (1982), "The Structure of Value: Accounting for Taste. In Affect and Cognition: The Seventeenth Annual Carnegie Symposium on Cognition. Hillsdale, NJ: L. Erlbaum Associates.

Cohen, J. B. (1982). The Role of Affect in Categorization: Towards a Reconsideration of the Concept of Attitude. Advances in Consumer Research. Association for Consumer Research (U. S.), 9(1), 94-101.

Czellar, S. (2003). Consumer attitude toward brand extensions: An integrative model and research propositions. International Journal of Research in Marketing, 20(1), 97-115. doi:10.1016/S0167-8116(02)00124-6

Durrani, M., \& Hussain, S. A. (2009). Brand Extension in Pakistan: Insight from Brand Manager Perspective [Master Thesis]. Jonkoping International Business School, Sweden.

Echambadi, R., Arroniz, I., Reinartz, W., \& Lee, J. (2004). Multicollinearity in Moderated Regression Models: A Critical Analysis of the Residual-Centering Method. JMR, Journal of Marketing Research.

Enz, C., Kosová, R., \& Lomanno, M. (2011). The impact of terrorism and economic shocks on U.S. hotels. Cornell Hospitality Report, 11(5), 1-17.

Fandos, C., \& Flavian, C. (2006). Intrinsic and extrinsic quality attributes, loyalty and buying intention: An analysis for a PDO product. British Food Journal, 108(8), 646-662. doi:10.1108/00070700610682337

Fu, G., \& Saunders, J. (2002). Consumer Evaluations of Brand Extensions: Empirical Evidences from China. Asia Pacific Advances in Consumer Research, 5, 395-399. 
Grime, I., Diamantopoulos, A., \& Smith, G. (2002). Consumer evaluations of extensions and their effects on the core brand: Key issues and research propositions. European Journal of Marketing, 36(11/12), 1415-1438. doi:10.1108/03090560210445245

Herr, P. M., Kardes, F. R., \& Kim, J. (1991). Effects of word-of-mouth and product-attribute information on persuasion: An accessibility-diagnosticity perspective. The Journal of Consumer Research, 17(4), 454-462. doi: $10.1086 / 208570$

Ishaq, M. I., Hussain, N., Asim, A. I., \& Cheema, L. J. (2014). Brand equity in the Pakistani hotel industry. Revista de Administração de Empresas, 54(3), 284-295. doi:10.1590/S0034-759020140304

Jalees, T. \& Ali, T. (2008). How Do Consumers Evaluate Brand Extension: A Five Factor Approach. Market Forces, (July), 9-17.

Kapferer, J. N. (2008). The new strategic brand management: creating and sustaining brand equity long term. Kogan Page Ltd.

Kimes, S. E. (2009). Hotel revenue management in an economic downturn: Results from an international study. The Center for Hospitality Research, 9(12).

Kotler, P., \& Armstrong, G. (2005). Principles of Marketing (11th ed.). New Delhi: Prentice hall of India Private Limited.

Lance, C. E. (1988). Residual Centering, Exploratory and Confirmatory Moderator Analysis and decomposition of Effects in Path Models Containing Interactions. Applied Psychological Measurement, 12(2), 163-175. doi:10.1177/014662168801200205

Larceneux, F., Benoit-Moreau, F., \& Renaudin, V. (2012). Why might organic labels fail to influence consumer choices? Marginal labelling and brand equity effects. Journal of Consumer Policy, 35(1), 85-104. doi:10.1007/ s10603-011-9186-1

Lee, J. A., \& Kacen, J. J. (2008). Cultural influences on consumer satisfaction with impulse and planned purchase decisions. Journal of Business Research, 61(3), 265-272. doi:10.1016/j.jbusres.2007.06.006

Li, H., Jiang, J., \& Wu, M. (2014). The effects of trust assurances on consumers' initial online trust: A twostage decision-making process perspective. International Journal of Information Management, 34(3), 395-405. doi:10.1016/j.ijinfomgt.2014.02.004

Loken, B., Barsalou, L. W., \& Joiner, C. (2008). Categorization theory and research in consumer psychology. In Handbook of consumer psychology (pp. 133-165). Academic Press.

Ma, H., Zhou, D., Liu, C., Lyu, M. R., \& King, I. (2011, February). Recommender systems with social regularization. In Proceedings of the fourth ACM international conference on Web search and data mining (pp. 287-296). ACM. doi:10.1145/1935826.1935877

Malt, B. (1989). An on-Line Investigation of Prototype and Exemplar Strategies in Classification. Journal of Experimental Psychology. Learning, Memory, and Cognition, 15(4), 539-555. doi:10.1037/0278-7393.15.4.539 PMID:2526852

Mather, D. W. (2011). Empirical Generalisations of Brand Extension Theory and the Role of General Linear Mixed Models. Unpublished PhD thesis, University of Otago, Dunedin, New Zealand.

Mazanec, J. A., \& Schweiger, G. C. (1981). Improved Marketing Efficiency through Multi-Product Brand Names? European Research, 9(1), 32-45.

Meenaghan, T. (1995). The role of advertising in brand image development. Journal of Product and Brand Management, 4(4), 23-34. doi:10.1108/10610429510097672

Meyers-Levy, J., \& Tybout, A. M. (1989). Schema Congruity as a Basis for Product Evaluation. The Journal of Consumer Research, 16(1), 39-55. doi:10.1086/209192

Müge Arslan, F., \& Korkut Altuna, O. (2010). The effect of brand extensions on product brand image. Journal of Product and Brand Management, 19(3), 170-180. doi:10.1108/10610421011046157 
Nijssen, E., \& Hartman, D. (1994). Consumer Evaluations of Brand Extensions: An Integration of Previous Research. In Proceedings of the 23rd. EMAC Conference (pp. 673-682). Academic Press.

O’neill, J. W., \& Carlbäck, M. (2011). Do brands matter? A comparison of branded and independent hotels' performance during a full economic cycle. International Journal of Hospitality Management, 30(3), $515-521$. doi:10.1016/j.ijhm.2010.08.003

Patro, S. K., \& Jaiswal, A. K. (2003). Consumer Evaluations of Brand Extensions: Evidence from India. Journal of Academy of Business and Economics, 1(2), 170-179.

Popper, K. R. (1959). The Logic of Scientific Discovery. London: Hutchinson.

Posner, M.I. \& Keele, S.W. (1968). On the Genesis of Abstract Thought. Journal of Experimental Psychology, 77(3), 353-363.

Prasad, K., \& Dev, C. S. (2000). Managing hotel brand equity: A customer-centric framework for assessing performance. The Cornell Hotel and Restaurant Administration Quarterly, 41(3), $22-31$. doi: $10.1177 / 001088040004100314$

Riley, D., Francesca, L., \& Wendy, B. A. (2004). Dove vs. Dior: Extending the Brand Extension DecisionMaking Process from Mass to Luxury. Australasian Marketing Journal, 12(3), 40-55. doi:10.1016/S14413582(04)70105-6

Saleem, H., Shahzad, M., Khan, M. B., \& Khilji, B. A. (2019). Innovation, total factor productivity and economic growth in Pakistan: A policy perspective. Journal of Economic Structures, 8(1), 7. doi:10.1186/s40008-0190134-6

Seo, S., \& Jang, S. S. (2013). The roles of brand equity and branding strategy: A study of restaurant food crises. International Journal of Hospitality Management, 34, 192-201. doi:10.1016/j.ijhm.2013.02.014

Shabbir, M. S. (2015). Innovation and Competitiveness Lead to Industrial Trade. Business and Economics journal, 3(4), 21-29.

Shabbir, M.S. (2016). The Impact of Advertisement on Buying Behavior of the Children. Arabian journal of Business and Management, 3(2), 1-11.

Shabbir, M. S., Ghazi, M. S., \& Mehmood, A. R. (2017). Impact of Social Media Applications on Small Business Entrepreneurs. Management and Economics Research Journal, (2).

Shabbir, M. S., \& Zaman, S. (2016). Marketing Strategic of Financial Services by Islamic Banks. Standard journal of Global business and Management, 3(2), 15-23.

Smith, S., \& Costello, C. (2009). Culinary tourism: Satisfaction with a culinary event utilizing importanceperformance grid analysis. Journal of Vacation Marketing, 15(2), 99-110. doi:10.1177/1356766708100818

Srull, T. K., \& Wyer, R. S. (1989). Person Memory and Judgment. Psychological Review, 96(1), 58-83. doi:10.1037/0033-295X.96.1.58 PMID:2648446

Stern, G. (1992, January 24). Marketing: Multiple Varieties of Established Brands Muddle Customers, Make Retailers Mad. Wall Street Journal.

Sujan, M. (1985). Consumer Knowledge: Effects on Evaluation Strategies Mediating Consumer Judgments. The Journal of Consumer Research, 12(1), 31.

Sunde, L., \& Brodie, R. J. (1993). Consumer Evaluations of Brand Extensions: Further Empirical Results. International Journal of Research in Marketing, 10(1), 47-54.

Tariq, M. I., Nawaz, M. R., Nawaz, M. M., \& Butt, H. A. (2013). Customer perceptions about branding and purchase intention: A study of FMCG in an emerging market. Journal of Basic and Applied Scientific Research, 3(2), 340-347.

Tauber, E. M. (1988). Brand Franchise Extension: New Product Benefits from Existing Brand Names. Business Horizons, 24(2), 36-41. doi:10.1016/0007-6813(81)90144-0

Zhou, L., Ye, S., Pearce, P. L., \& Wu, M. Y. (2014). Refreshing hotel satisfaction studies by reconfiguring customer review data. International Journal of Hospitality Management, 38, 1-10. doi:10.1016/j.ijhm.2013.12.004 